\title{
Neo-liberalism and the Politics of Higher Education Policy in Indonesia
}

\author{
by \\ Andrew Rosser \\ andrew.rosser@adelaide.edu.au \\ Ph: +61 883034938 \\ c/o School of Social Science, University of Adelaide, Adelaide SA 5005 Australia \\ Corresponding Author: Andrew Rosser \\ Paper resubmitted to Comparative Education
}

April 2015

\section{Notes on Contributor}

Andrew Rosser is Associate Professor of Development Studies at the University Adelaide. $\mathrm{He}$ is currently working on a research project focused on law, politics and socio-economic rights in Indonesia courtesy of an Australian Research Council Future Fellowship. His other work on the politics of education policy in Indonesia has been published in Journal of Development Studies, Pacific Affairs, Asian Studies Review, and The Asia-Pacific Journal of Anthropology. 


\begin{abstract}
This paper examines Indonesia's experience with neoliberal higher education reform. It argues that this agenda has encountered strong resistance from the dominant predatory political, military and bureaucratic elements who occupy the state apparatus, their corporate clients, and popular forces, leading to continuation of the centralist and predatory system of higher education that was established under the New Order. The only areas in which neoliberal reform has progressed have been those where the neoliberal agenda has aligned well with that of popular forces and there has been little resistance from predatory elements. In presenting this argument, the paper illustrates the role of domestic configurations of power and interest in mediating global pressures for neoliberal higher education reform. It accordingly suggests that Indonesia needs to construct a model of higher education that simultaneously fits with the reigning political settlement and produces better research and teaching outcomes than the present model.
\end{abstract}

\title{
Keywords
}

Indonesia, higher education, politics, political settlements, neo-liberalism, autonomy, foreign universities, accreditation

\section{Acknowledgements}

I have benefited enormously from conversations with Phil King, Donni Edwin, and numerous others who would prefer to remain nameless. This work was supported by the Australian Research Council under grant number FT110100078. The usual caveat applies. 


\section{Introduction}

Recent decades have witnessed the emergence of a new reform agenda for higher education in developing countries. Founded on neoliberal principles, this agenda has entailed policy measures aimed at: i) enhancing the managerial, financial, and academic autonomy of higher education institutions (HEIs) (e.g. legislative changes transforming HEIs into autonomous entities; the devolution of responsibility for managing HEIs from the state to HEIs themselves; the introduction of funding arrangements giving HEIs more control over resources and encouraging them to expand income sources; and the withdrawal of the state from involvement in the appointment of university executives and managers); ii) promoting greater competition between HEIs (e.g. the encouragement of greater private sector involvement in the higher education sector including, in some cases, the establishment of branch campuses of foreign universities; and the creation of competitive mechanisms for allocating public research and teaching funds); and iii) enhancing HEIs' accountability for the use of public funding (e.g. the establishment of external agencies that accredit HEIs and their programs; and the introduction of new reporting requirements against state and institution determined goals) (Fielden 2008, 43; Johnstone et al 1998). The need for such measures has been rationalised in terms of the scarcity of public funding for higher education, perceived mismatches between HEI offerings and student and labour market needs, and the link between autonomy and academic freedom (World Bank 2000; 2012).

The emergence of this agenda has reflected economic globalisation and the development of the knowledge economy, both of which have created pressure for developing countries to improve access to and the quality of their higher education systems in order to enhance national economic competitiveness (Torres and Schugurensky 2002; Arnove 2009; Naidoo 2011). It has been actively promoted by international organisations such as the World Bank and the Organisation for Economic Cooperation and Development (OECD) and gained support from key sections of the international business community (Bassett and MaldonadoMaldonado 2009; Verger et al 2014). For both these reasons, it has been enormously influential in developing countries. Yet the extent to which governments in these countries have adopted neoliberal higher education reforms has varied considerably from case to case with the result that there has been continued heterogeneity in the nature of developing country higher education systems (Torres and Schugurensky 2002; Naidoo 2011, 47; Varghese 2013; Varghese and Martin 2013b). A small number of countries-most notably, Cuba and Venezuela - have rejected the neo-liberal model altogether in favour of socialist alternatives (Muhr and Verger 2009; Naidoo 2011, 48). More commonly, developing countries have selectively blended elements of the neoliberal model together with preexisting state-led systems to produce new and distinctive national hybrids (Mok 2008; Marginson 2011).

This paper considers the Indonesian case. It argues that efforts to promote the new reform agenda in that country have run aground in the face of fierce resistance from the dominant predatory political, military and bureaucratic elements who occupy the state apparatus, their corporate clients, and popular forces. Technocratic proponents of neoliberal reform and their supporters in the donor community have won a number of key policy 
changes since the late 1990s. But they have not been able to ensure their effective implementation in practice or prevent successful challenges to their agenda through the courts and lobbying. The result has been continuation of the centralist and predatory system of higher education established under the New Order (the authoritarian regime that ruled Indonesia from 1965 to 1998) rather than a marked shift towards the neoliberal model. The only area in which the technocrats and their donor supporters have had any degree of success has been in relation to academic freedom, an area where their agenda has aligned well with that of popular forces and there has been little resistance from the dominant predatory elements.

In presenting this argument, this paper seeks to contribute to our understanding of the way in which domestic political and social factors mediate global pressures for neoliberal higher education reform in developing countries. Torres and Schugurensky $(2002,429)$ have noted that 'global trends [in higher education] are promoted, resisted and negotiated differently in each national context'. Similarly, Naidoo $(2011,47)$ has argued that 'while developing countries are influenced by global templates of higher education, at the same time particular aspects of such templates are also transformed, excluded and adapted in line with each country's own historical trajectories, cultural influences and socialpolitical milieus' (see also Marginson et al 2011). But so far scholars of comparative education have done little to analyse exactly how domestic political and social factors work to shape reform outcomes in developing countries. ${ }^{1}$ Drawing on the political settlements framework devised by Khan (2010), this paper suggests that the interests and agendas of competing domestic political and social actors, the relationships of power between them, and the way these shift over time are central to this process of mediation.

In presenting this argument, the paper begins by briefly outlining an approach to understanding the politics of higher education in developing countries based on the political settlements framework. It then provides an overview of key features of Indonesia's higher education system; identifies the main sets of actors who have been involved in higher education policy-making and its implementation in that country; examines their respective interests, policy agendas and forms of leverage; and analyses the way in which contests between these sets of actors, interests and agendas have shaped the extent and pattern of neoliberal higher education reform since the mid-1990s. The final section of the paper presents the conclusions.

\section{Understanding the Politics of Higher Education in Developing Countries: A Political Settlements Approach}

The political settlements framework represents a blending of ideas associated with the new institutional economics (NIE) and ideas associated with critical traditions in political economy, in particular, Marxism. The starting point for the framework is the notion that 'institutions'- that is, the rules, regulations and enforcement mechanisms that govern economic and social activity (North 1990)—not only shape economic growth prospects—as

\footnotetext{
${ }^{1}$ The mediating effects of domestic political and social factors have received greater attention in work on higher education reform in developed countries. See, for instance, Graf (2009) and Powell and Solga (2010).
} 
many new institutional economists have shown - but also the distribution of resources within society. It accordingly proposes that institutional structures reflect relationships of power and interest and that institutional change is a matter of political and social struggle. Some new institutional economists have suggested that institutional change is driven either by a functionalist demand for improved economic efficiency or shifts in cultural values and cognitive abilities as a result of learning (North 1989; 1994). To the extent that they have incorporated a concern with politics, they have portrayed it as an obstacle to growthpromoting institutional reform rather than the process through the conditions for such reform are either created or blocked (Rosser 1999). The political settlements approach, by contrast, proposes that politics should be placed at the centre of the analysis and seen as the primary determinant of all institutional change regardless of whether it is growth-promoting or growth-retarding.

Khan $(2010,4)$ has defined a 'political settlement' as: 'a combination of power and institutions that is mutually compatible and also sustainable in terms of economic and political viability'. The institutions and the distribution of power, he argues, 'have to be compatible because if powerful groups are not getting an acceptable distribution of benefits from an institutional structure, they will strive to change it' $(2010,4)$. The implication is that institutions are subject to change over time as a result of shifts in the balance of power between competing actors. Another implication, as Parks and Cole (2010, viii) have noted, is that the institutions that form part of political settlements are not limited to formal written agreements - such as peace agreements - that are signed in the wake of specific historical events (such as civil wars). Such institutions, they suggest, 'should be understood as rolling agreements among powerful actors that are constantly subject to renegotiation and contestation' (2010: 6).

The core concepts associated with the political settlements approach are actors, interests, and institutions (Parks and Cole 2010, 6). The latter is understood essentially in Northian terms as described above. With regards to actors and interests, the focus is on elite groups such as politicians, large capitalists, government technocrats, donors, and predatory bureaucrats, reflecting the fact that these are typically the most powerful groups in developing countries (di John and Putzel 2009). In general, non-elite groups are excluded from the analysis on the grounds that they occupy a subordinate position in the power structure and cannot therefore participate effectively in the construction of institutional arrangements. However, some recent contributions (for instance, Hickey et al 2015) have sought to incorporate 'popular forces' such as workers, peasants and NGO activists into the political settlements framework, in recognition of the fact that, while elite actors generally dominate policy-making and implementation processes in developing countries, popular actors can play a significant role, particularly when empowered by democratic reform or structural change in the economy and society. In these circumstances, popular forces can become party to the political settlements that determine the institutional arrangements governing economic and social activity.

So far, the political settlement approach has primarily been used to explain differences in economic institutions and growth rates in developing countries (see, for 
instance, Khan 2010; 2012). To apply it to the case of neoliberal higher education reform entails:

1) conceptualising higher education policy and its implementation as a set of institutions - that is, a set of rules, regulations and enforcement mechanisms;

2) recognising that these institutions have consequences not just in terms of overall educational and economic outcomes (university enrolment rates, qualification levels, innovation levels etc.) but also the distribution of resources and opportunity with society. In particular, they affect who has access to higher education, the income benefits that accrue as a result of having a higher education, and the financial benefits stemming from control over government funding; and

3) understanding the extent and pattern of neoliberal higher education reform in terms of the extent to which key actors' interests align or diverge in relation to reform initiatives. This in turn entails identifying the actors who are involved in contesting higher education policy and its implementation in specific contexts and understanding how particular institutional arrangements serve or harm their interests. It also entails understanding the evolution of higher education policy and its implementation in terms of continuities and shifts in the balance of power between actors. Finally, it entails recognizing that the extent of alignment between the interests of key actors may vary by reform measure: while all key actors may agree on the need for some measures, they may disagree on the need for others.

In the following sections, we use this analytical framework to explain the extent and pattern of neoliberal higher education reform in Indonesia in the wake of emerging global pressures for such reform since the mid-1990s. In broad terms, the argument is that neoliberal higher education reform has been limited in nature because the major political and social forces in Indonesia have had diverging interests and agendas vis-a-vis reform. Reform has only made significant headway in areas where their interests have been aligned or at least not significant contradictory. Before embarking on this analysis, however, it is necessary to briefly note the following key features of Indonesia's higher education landscape.

\section{Key Features of Indonesia's Higher Education System²}

Indonesia's higher education system includes six main types of institution: universities, institutes, colleges (sekolah tinggi), polytechnics, academies, and community academies.

\footnotetext{
${ }^{2}$ The analysis in this and following sections draws on both primary and secondary sources of material, much of which was collected during fieldwork in Jakarta, the national capital, during a series of trips between 2012 and 2014. The key source of primary data was interviews with individuals who had specialised knowledge about Indonesia's higher education system and, in particular, the policy and implementation issues examined below. Informants included government officials, NGO and student activists, academics, donor agency officials, and HEI employees. In total, 20 individuals were interviewed. Secondary sources included laws and regulations on higher education, government and NGO reports, court documents, previous academic studies, and newspaper and magazine articles. With respect to the latter, the research made particular use of the sources available through Factiva; the Kompas Information Centre (a private library run by one of Indonesia's major media companies); the Centre for Strategic and International Studies' clipping service; and Indonesian media companies' websites.
} 
These are distinguished from one another by the breadth of their disciplinary offerings and the level of qualifications they award with universities sitting at the top of the hierarchy because they offer the greatest range of disciplinary programs and highest level of qualifications . Another key distinction is between state and private HEIs. State HEIs account for only a small proportion of the total number of HEIs in Indonesia but almost 40 percent of enrolments. State HEIs receive government funding but also generate revenue through student tuition fees, donor grants, philanthropic donations, and private sector contracts. In recent years, tuition fees in particular have become increasingly important. By contrast, private HEIs are funded mainly through tuition fees and other private contributions (Buchori and Malik 2006, 250-251). In geographical terms, the distribution of HEIs is skewed towards Java and two major regional hubs (North Sumatra and South Sulawesi) reflecting demographic trends and the associated opportunities that large urban centres offer to universities and their students.

Primary responsibility for managing the higher education system lies with the Ministry of Education and Culture $(\mathrm{MoEC})^{3}$ and, in particular, the Directorate-General for Higher Education (DGHE). ${ }^{4}$ Although authority over education policy and management was decentralised to local (district and provincial) governments in 2001, this did not extend to higher education policy. DGHE has accordingly continued to coordinate, supervise, and direct all state and private HEIs. In addition to MoEC/DGHE, a number of other ministries and agencies also play a part in HEI management, most notably the Ministry of Religious Affairs (MoRA) which is responsible for funding State Islamic Universities (UIN) and regulating matters related to religious education. Others include the Ministry of the State Apparatus and Bureaucratic Reform (MENPAN-RB) and Civil Service Agency (BKN) which set conditions related to civil service employment (of crucial importance given that many staff in state HEIs and some in private HEIs are civil servants); the Ministry of Finance (MoF) which regulates the financial management of state institutions; and ministries that directly oversee HEIs related to their portfolios - for instance, the Ministry of Home Affairs (which oversees the Home Affairs Administration Institute) and the Ministry of Defence (which oversees the Indonesian Defence University).

\section{Actors and Interests}

Broadly speaking, four main sets of actors have played a role in higher education policymaking and implementation in Indonesia in recent decades. The first of these has been technocratic officials in government and their allies in the donor community. These actors have been strong proponents of the neoliberal higher education agenda outlined above. They have also advocated neoliberal policies in other domains of policy and, most importantly for our purposes, conservative fiscal management. For a long time, this orientation entailed a reluctance to spend significant public funds on education and, to the extent it was necessary,

\footnotetext{
${ }^{3}$ The Ministry was known as the Ministry of National Education from 1999 to 2009 with Culture being placed in a joint Ministry with Tourism.

${ }^{4}$ In October 2014, newly-elected President Joko Widodo removed the DGHE from MoEC and merged it with the Ministry for Research and Technology, creating a new Ministry for Research, Technology and Higher Education.
} 
a preference for spending on school (especially basic) rather than higher education (Prawiro 1998, 178-181; Salmi et al 2009). But as the focus of global development policy has shifted towards creating 'knowledge economies' since the 1990s, these actors have supported modest increases in public investment in higher education so long as it is accompanied by governance reforms to enhance quality, choice, accountability and so forth and efforts to mobilise funding from private sources including the charging of tuition fees (Salmi et al 2009; World Bank 2010). The influence of these actors has been substantial, reflecting support from the domestic and international business communities, both of which have had an interest in conservative fiscal management (at least to the extent this implies low corporate taxation) and the creation of opportunities for private investment in the higher education sector, and the leverage that donor organisations have had by virtue of their control over mobile investment resources ${ }^{5}$. This coalition has had access to the policy-making process due to the fact that economic ministries - especially, the Ministries of Finance, Trade, and National Development Planning (Bappenas) - have generally been led by technocratic ministers and MoEC has also had substantial in-house technocratic staff (World Bank 2004, ix). ${ }^{6}$

Key individual actors in this coalition have included members of the so-called 'Berkeley Mafia', the team of economic technocrats who were President Suharto's main economic advisors during the New Order; ${ }^{7}$ Bambang Soehendro (Director-general of Higher Education in the mid-1990s); Bambang Sudibyo (Minister of Finance between 1999 and 2000 and Minister of National Education between 2004 and 2009); Mari Pangestu (Minister of Trade between 2004 and 2011 and Minister for Tourism and Creative Industries between 2011 and 2014); Sri Mulyani Indrawati (Head of Bappenas between 2004 and 2005, Minister of Finance between 2005 and 2010, and Coordinating Minister for the Economy between 2008 and 2009); Boediono (Head of Bappenas between 1998 and 1999, Minister of Finance between 2001 and 2004, Coordinating Minister for the Economy between 2005 and 2008, Governor of Bank Indonesia between 2008 and 2009; and Vice-President from 2009 to 2014); Fasli Jalal (various Director-General-level positions in MoEC between 2001 and 2010 including in DGHE and Vice Minister of National Education from 2010 to 2011); and Satrio Soemantri Brojonegoro (Director-general of Higher Education from 1999 to 2007). ${ }^{8}$ Within the donor community, the World Bank has been the most crucial advocate of this agenda (World Bank 1998, 2010).

The second set of actors has been the predatory political, military and bureaucratic figures who occupy the state apparatus, the corporate entities to which they are linked (often through family, friendship or political party ties), and the larger patronage networks of which both are part. These actors have had an interest in maximizing political and bureaucratic control over both public and private HEIs so as to create opportunities for corruption and rent extraction. They have also had an interest in maximizing control over the government's

\footnotetext{
${ }^{5}$ See Winters (2006) on the link between capital mobility and structural leverage.

${ }^{6}$ For instance, see World Bank (2004: ix) for a list of key technocratic staff in MoEC.

${ }^{7}$ Leading members of the Berkeley Mafia include Widjojo Nitisastro, Ali Wardhana, Sumarlin, Emil Salim, and Radius Prawiro.

${ }^{8}$ See Prawiro (1998, 178-181), Jalal and Mustafa (2001), and Brodjonegoro (2012) for statements of the views members of this camp.
} 
higher education budget and in particular funds for procurement of equipment, supplies and construction services at public HEIs because most of the government's higher education budget has been spent on support to these institutions rather than private HEIs. These actors have exercised influence over higher education policy-making and implementation by virtue of their direct occupation of the state apparatus (in the case of predatory political and bureaucratic figures) and access to policy-makers via 'brokers' or intermediaries (in the case of predatory business figures). Key actors in this coalition have included various members of the national parliament's education and budget committees (which are responsible for approving government spending in the higher education sector), various senior bureaucratic officials (who initiate spending proposals), business groups with strong bureaucratic and political connections, and many senior managers at public HEIs. The identities of these individuals are often difficult to determine with any certainty because they generally operate behind the scenes. However, some were exposed as a result of the Angela Sondakh affair (see below).

The third set of actors has been the individuals and organisations behind Indonesia's numerous private HEIs. The vast majority of private HEIs in Indonesia are managed by nonprofit charitable foundations (yayasan). Yet many are run as private businesses or vehicles through which religious organisations generate revenue, build social bases, and mobilise support for favoured political parties and candidates. The major Islamic organisations, Muhammadiyah and Nahdatul Ulama, have been particularly important as owners and operators of private HEIs, each having extensive networks of such institutions. Increasingly private business groups/people have been active in running private HEIs including the Lippo Group (which owns Pelita Harapan University), Ciputra (which owns Ciputra University), and Tanri Abeng (who owns Tanri Abeng University). Government regulation of the higher education sector has historically focused much more on public HEIs than private HEIs, so the owners of private HEIs have tended to be less engaged in contests over higher education policy than the other sets of actors mentioned here. They have, however, had a collective interest in protection from foreign competition, access to state education resources, and continued yayasan control over private HEIs. In general, they have engaged on a one-to-one basis with the government (especially DGHE) over regulatory issues but where collective interests have been concerned, they have operated through lobby groups such as the Association of Governing Bodies of Indonesian Private Higher Education Institutions (ABPPTISI) and the Association of Indonesian Private Higher Education Institutions (APTISI). There is enormous diversity among the individuals and organisations behind private HEIs. But to the extent that they have engaged in corruption to gain regulatory approvals, favourable accreditation ratings or government training contracts or participated in political and bureaucratic campaigns to secure control over state resources (e.g. by acting a base through which political candidates mobilise support or assisting individual bureaucrats 'purchase' higher positions ${ }^{9}$ ), they have had close links to, even overlapped with, the second set of actors. ${ }^{10}$

\footnotetext{
${ }^{9}$ On the purchase and sale of government offices, see McLeod (2000) and Kristiansen and Ramli (2006).

${ }^{10}$ For instance, a number of senior MoEC officials are involved in running private HEIs.
} 
The fourth set of actors is popular elements such as activists at progressive NGOs, university student groups, and nationalist and left-wing academics. Members of this coalition have promoted a policy agenda that combines rights-based approaches to development, opposition to privatisation and deregulation, nationalism and radical populism. Their key interests have been to promote citizens' rights of access to education, ensure equality, and build national identity and resilience through the education system, although the relative emphasis placed on these elements has varied from actor to actor with NGO activists, leftwing academics and university student groups tending to be stronger on rights and equality and nationalist intellectuals tending to be stronger on national identity and resilience. They have been 'progressive' in the sense of being opposed to 'conservative' agendas such as neoliberalism and neo-colonialism. Members of this coalition have generally been excluded from the education policy-making process, ${ }^{11}$ but able to play some role by shaping public opinion through the media and challenging government policies in the courts, especially the Constitutional Court. Key actors have included activists at Indonesia Corruption Watch (ICW) (a prominent Jakarta-based anti-corruption NGO), the Institute for Education Reform (an advocacy group based at Paramadina University), and the Jakarta Legal Aid Bureau (a LBH Jakarta) (a human rights NGO); members of Student Executive Councils (Badan Eksekutif Mahasiswa) at major state universities; nationalist intellectuals such as Professors HAR Tilaar, Winarno Surakhmad, and Soedijarto, all of whom are based at Jakarta National University; figures associated with Taman Siswa (a nationalist education organisation that played a key role during Indonesia' struggle for independence against the Dutch) such as Darmaningtyas; and left wing academics such as Heru Nugroho (Gadjah Mada University) and Syamsul Hadi (University of Indonesia). ${ }^{12}$

In the following sections, I illustrate how continuities and shifts in the balance of power between these sets of actors during the New Order and post-New Order periods have influenced the nature of higher education policy in Indonesia and its implementation. In other words, I illustrate how the political settlement between them in relation to higher education has endured/changed over time. I focus on three issues in particular-HEI autonomy, the entry of foreign HEIs, and accreditation - to illustrate the political dynamics at work and the outcomes that have prevailed. In broad terms, I argue that the continued political dominance of predatory political, military, bureaucratic and corporate elements throughout both these periods and the growing political influence of popular forces since the fall of the New Order has severely limited the scope for neoliberal higher education reform. The exception has been where this agenda has intersected with that of popular forces and attracted little opposition from predatory ones.

\section{The Political Economy of Higher Education Reform During the New Order}

The 'New Order' was dominated by predatory military and bureaucratic officials and the dominant sections of domestic and foreign capital. After seizing power in a coup in 1965, the

${ }^{11}$ Certainly, this is how the activists themselves see things. Interviews with Ade Irawan, ICW, and Lody Paat, Education Coalition, both Jakarta, November 2012.

${ }^{12}$ See Nugroho (2002), Irawan (2007); Hadi (2007), Darmaningtyas et al (2009), Soedijarto (2008), and Tilaar (2012). 
leaders of the Indonesian military reduced the national parliament to a rubber stamp and secured control over the bureaucracy and judiciary. They carried out a dramatic simplification of the political party system, fusing separate and mutually antagonistic political parties into new coalitions, and intervened extensively in their affairs. At the same time, they integrated current and former military officials into senior positions in the bureaucracy, cabinet, parliament and state-owned enterprises such as Pertamina (the state oil company) and Bulog (the national logistics agency), permitting them to use these positions for rentseeking activities. They also subordinated the judiciary to political and bureaucratic authority, ensuring that it remained politically compliant and embedded in the New Order's predatory networks.

Facing an economic crisis at the time of their accession to power, they accepted large amounts of foreign aid and policy advice from the IMF, the World Bank and the InterGovernmental Group on Indonesia (IGGI) (a consortium of the country's main bilateral donors), and sought to attract domestic and foreign capital-which had fled under the previous regime - back into the country. In so doing, they forged an effective alliance with controllers of mobile capital. In this context, they granted broad authority over macroeconomic and fiscal policy to the 'Berkeley Mafia'. Over time, they also nurtured the emergence of a group of large private business conglomerates, many of which were owned by ethnic Chinese entrepreneurs or politically well-connected indigenous entrepreneurs and involved in large scale industrial projects with foreign investors. The best known of these were the business groups owned by the friends and relatives of President Suharto. Many of these enterprises secured state protection for their investment projects and privileged access to state facilities such as state bank credit, forestry concessions, licenses and government supply and construction contracts (see Robison 1986; Winters 1996; Rosser 2002; and Rosser et al 2005).

By contrast, popular forces—such as university students, workers, peasants, and NGO activists - played little role in policy-making and implementation, reflecting the New Order's strategy of 'disorganising' civil society (Robison and Hadiz 2004). This strategy had several components: i) emasculation of the political parties; ii) the establishment of corporatist organisations with monopolies on the representation of specific social groups that, although ostensibly meant to represent these groups, in practice served to control them and limit their impact on policy (Maclntyre 1990, 23-31); iii) the imposition of restrictions on press freedom and academic freedom (Lubis 1993; Hill 1994); and iv) the efforts to ensure ideological uniformity through the promotion of Pancasila, the state ideology, and the imposition of requirements for social organisations to adopt Pancasila as their 'sole foundation'. In this context, it became more or less impossible for popular forces to establish well-organised, well-funded and politically independent organisations representing their interests. A significant NGO movement emerged during the 1980s and 1990s with the support of foreign donations and donor funds. But only a few NGOs were able to establish broad organisational structures and all were constrained by the New Order's political controls (Rosser et al 2005, 58).

Within this context, the Indonesian government invested little in the country's higher education system. It invested heavily in expanding the size and geographic reach of the 
education system and improving access to education, especially during the oil boom years of the 1970s and early 1980s when it had substantial discretionary investment funds at its disposal. But its efforts in this respect were focused on the school system, in particular, basic education (Prawiro 1998, 178-181). The New Order period witnessed growing demand for higher education as a result of rising income levels (a product of high rates of economic growth); demographic change (in particular, an increase in the number of university-age people); and an increase in the number of students progressing through the school system as a result of the latter's expansion. This led to a marked increase in student enrolments at HEIs both in aggregate and as a proportion of the relevant age group (see Figures 1 and 2). But with technocratic officials and donor organisations stressing the need for fiscal rectitude and for government education funding to be concentrated on the school sector (Prawiro 1998; Robison 1986: 373-399), the government decided to accommodate this demand through an expansion of privately-provided higher education rather than the establishment of large numbers of new public HEIs (Idrus 1999, 136). The result was a huge increase in the number of private HEIs so that by the mid-1990s they far outnumbered their public counterparts.

\section{INSERT FIGURES 1 AND 2 ABOUT HERE}

At the same time, the government pursued a 'centralist' (Idrus 1999) and predatory approach to management of the higher education system, key features of which were limited autonomy for HEIs (particularly public HEIs), restricted competition, and poor quality control.

\section{Autonomy}

Law 2/1989 on a National Education System guaranteed HEIs 'autonomy in the management of their institutions as centres of higher education and scientific research' (Article 22 (2)). But this provision was largely ignored in practice under the New Order. Public HEIs were formally units within the bureaucracy rather than separate legal entities and their staff were classified as civil servants. As such, they had virtually no managerial or financial autonomy from government. University rectors and other HEI leaders were appointed by the government typically from among existing academic staff at the institution rather than through open, competitive processes. Even straightforward management-related matters such as travel for senior HEI staff and the introduction of new courses and degree programs required approval from MoEC. On the financial side, HEIs received pre-allocated line-by-line budgets from the centre rather than block grants, denying them any significant discretion in the use of allocated funds (Brodjonegoro 2012). Private HEIs were in general subject to less bureaucratic intervention and control with yayasan-dominated boards typically being responsible for their management. But they were nevertheless closely monitored by MoEC through a series of regional Private University Coordinating Offices (Kopertis). Finally, HEI autonomy in academic affairs was also severely constrained: free academic inquiry and debate was limited by the authoritarian nature of New Order rule and, in particular, its controls on freedom of expression, restrictions on student political activity, and use of the education system (including HEIs) to promote political obedience and nation-building 
through compulsory teaching of the state ideology, Pancasila, and the use of Bahasa Indonesia as the medium of instruction (Human Rights Watch 1998; Leigh 1999; Nugroho 2005).

This centralist approach in turn made public HEIs part of the larger 'franchise' structure that characterised the New Order, the key feature of which was the purchase of government positions in exchange for access to the rents they could generate (McLeod 2000). The government's strict control over senior HEI appointments, restrictions on academic freedom, and widespread corruption within the civil service combined to create a context in which senior management positions at HEIs could be sold to the highest bidder. Academic staff at public HEIs had little incentive to excel in teaching and research given the limited recognition of accomplishments in these areas in public service regulations and procedures and the overriding compulsion for them to show loyalty towards the state (Cummings 1981, 39-40; Idrus 1999: 136). Rather, they had an incentive to focus on securing senior administrative positions that provided opportunities for income supplementation through perks of office and corruption (Nugroho 2005, 155). Forms of corruption included the award of HEI supply and construction contracts to businesses in exchange for kickbacks; the extraction of fees from grants or consultancies won by junior staff; and the sale of university places to prospective students willing to pay bribes (Watson 1986; Sujatmoko et al 1998). Alternatively, academic staff had an incentive to pursue external income generating opportunities such as consultancies and teaching opportunities at other HEIs even if this meant abandoning teaching responsibilities at their home institution (Cummings 1981, 4546).

\section{Competition}

Although the New Order witnessed a massive expansion in the number of private HEIs, competition for students was limited by the privileges extended to public HEIs, particularly the major public universities. Public HEIs attracted the bulk of government higher education funding, helping them become simultaneously better quality and cheaper on average than their private competitors. Private HEIs consequently competed for students in the 'spillover' market - that is, the market for students rejected by public HEIs. With lower levels of public subsidy and lower quality students, they typically offered a lower quality education but charged higher fees. The main exceptions to this market positioning were a small number of private HEIs established in major urban centres such as Jakarta, Yogyakarta and Surabaya (e.g. Triskati, Tarumanegara, Atma Jaya) catering to the country's emerging middle class, in particular its ethnic Chinese component (ethnic Chinese students experienced discrimination in gaining access to the major public universities and so generally pursued higher education in the private sector) (Chua 2004, 472). The privileged position of the major public universities and other public HEIs was also reinforced by a blanket ban on the entry of foreign HEIs ${ }^{13}$ and the absence of genuinely competitive mechanisms for allocating public research and teaching funds.

${ }^{13}$ Article 120 (1), Government Regulation 30/1990 on Higher Education. 


\section{Accreditation/Quality Control}

Under the New Order, the government did little to ensure the quality of public or private HEIs through accreditation processes. On the one hand, as Buchori and Malik (2004, 264) have noted, public HEIs were not subject to formal accreditation processes because 'the legitimacy and inherent quality of public universities was taken for granted'. They were rather taken as the benchmark by which the quality of private HEIs should be assessed. On the other hand, accreditation processes for private HEIs lacked rigour and transparency. The government classified private HEIs into three quality-based categories - equalized (i.e. equivalent in standard to public HEIs), recognised and, registered. At the same time, it also required students at private HEIs with accreditation ratings of recognised or registered to sit final examinations organised by kopertis at a designated public university before receiving their degrees. This system was generally ineffective, as Prof. Dr. Joetata Hardihardjaja (1996, 44), Director for Private Universities at MoEC in the mid-1990s, candidly observed, because of a combination of under-resourcing for accreditation activities and fraudulent behaviour by private HEIs: 'Data on [private HEIs] being reported to the government in many cases do not fit with the real condition of the campus life. The false reports are made by the [private HEIs] to maintain their current status or standing and the Office of Private Higher Education cannot check and match every detail with the [private HEIs'] physical entities due to the limited number of staff and because there are a great number of universities.' At the same time, the state examination was a 'relatively weak' quality assurance mechanism 'because there are many committees that handle a great number of subject matters for different levels/strata of education.'

\section{The New Paradigm}

To address concerns about quality and equity, government technocrats, working in conjunction with the World Bank, persuaded the New Order government to adopt a new policy framework for higher education in the mid-1990s that shifted away from a centralist approach to higher education to one informed broadly by neoliberal principles. Known as the 'New Paradigm in Higher Education' and built into the government's Long-term strategy for Higher Education for 1996-2005, the new framework emphasised the principles of autonomy, quality, accountability, accreditation, and evaluation (Moeliodihardjo et al 2001). But the government moved slowly in implementing this framework before the fall of the New Order. It did nothing, for instance, to provide public HEIs with greater autonomy either in terms of managerial and financial autonomy or in terms of academic freedom (Human Rights Watch 1998; Idrus 1999). In 1994, the government established the National Accreditation Agency (BAN) to assess the quality of HEIs and their programs. But it was only in 1998 that it made such assessments compulsory for HEIs. With World Bank support, the government also established two new competitive funding mechanisms for universities in the mid-1990s: the University Research for Graduate Education (URGE) project (which provided research grants and fellowship opportunities to units at public HEIs that conducted postgraduate programs) and the Development of Undergraduate Education (DUE) project (which provided block grants to advance the teaching quality of undergraduate programmes at a select group of public HEIs) (see Nizam 2006, 40; Wicaksono and Friawan 2011, 182). These, however, 
were essentially pilot activities that serviced a limited group of HEIs, all within the public sector.

Nor did the government do much to generate greater competition for students, particularly by allowing the entry of foreign HEIs. In 1997-1998, for instance, Education Minister Wardiman Djojonegoro announced that foreign HEIs would be allowed to operate in Indonesia through joint ventures with Indonesian parties on condition that they adopted between 50 and 80 percent of the Indonesian national curriculum (Kyodo News 1997; Jakarta Post 1998). In a Government Regulation issued days before President Suharto's resignation in May 1998, the government further specified that such joint ventures should fulfil all the requirements and regulations that are valid for private HEIs in Indonesia and pass a MoEC evaluation. ${ }^{14}$ But such conditions proved unattractive to foreign HEIs and over the next few years, only one foreign HEI - the Swiss-German University in Jakarta — was established as a domestic private university. ${ }^{15}$

In sum, then, Indonesia's higher education system under the New Order bore little resemblance to the neoliberal model being actively promoted by that time by technocratic government officials and donor organisations except to the extent that it was highly privatised and built on limited public funding. Rather than being characterised by autonomy, competition, and accountability, its key features were instead hefty state control, segmented competition, and widespread predation and corruption. This reflected the political dominance of predatory political, military and bureaucratic elements and their corporate clients as well as the influence they granted to government technocrats in relation to macroeconomic and fiscal policy. It also reflected the relative political weakness of popular forces supporting rightsbased and nationalist approaches to higher education.

\section{The Political Economy of Higher Education Reform Since the New Order}

The onset of economic crisis in 1997 and subsequent collapse of the New Order in 1998 shifted power in favour of government technocrats and donors and away from predatory elements in so doing created a political context more conducive to neoliberal higher education reform. On the one hand, these developments led to a transition towards a democratic and decentralized political system ${ }^{16}$ more compatible with technocrats' and donors' emphasis on managerial and financial autonomy for HEIs and the principle of academic freedom. On the other hand, the economic crisis dramatically strengthened the structural leverage of foreign donors, at least for the period of the crisis. By precipitating widespread corporate bankruptcy, the crisis undermined the economic base of predatory politicians, bureaucrats and their corporate clients; and, by simultaneously increasing the country's public debt and undermining sources of government revenue, it forced the government to negotiate a rescue package with the International Monetary Fund (IMF) and accept increased aid. While the IMF package did not address education policy issues beyond the introduction of new social safety net programs for schoolchildren, it created an

\footnotetext{
${ }^{14}$ Government Regulation 57/1998 on an Amendment to Government Regulation 30/1990 on Higher Education.

${ }^{15}$ Interview with Satrio Soemantri Brodjonegoro, Jakarta, November 2012.

${ }^{16}$ Competitive elections for the national parliament were first held in June 1999 and then again in 2004, 2009 and 2014. Decentralisation was legislated for in 1999 and implemented in 2001.
} 
environment in which government technocrats and international donors were able to exercise greater influence over government policy, including higher education policy, than they had under the New Order. ${ }^{17}$

Within this context, the World Bank pushed hard for reform of Indonesia's higher education system working closely with government technocrats in Bappenas and MoEC. In September 1998, it published a major report on Indonesia's education system that called for, among other things, increased autonomy for HEIs and an opening up of the higher education sector to foreign HEIs (World Bank 1998). Immediately afterward, it then co-funded with Bappenas the establishment of a series of Task Forces to prepare reports on key education policy issues including higher education (Jalal and Musthafa 2001, viii-x). Drawing on the 1996-2005 Long-term Strategy for Higher Education, this report provided the intellectual rationale for a major shift in higher education policy in favour of neoliberal reform. Over the next few years, donors provided loans and grants to the Indonesian government to support the reform agenda, most notably the World Bank through the Managing Higher Education for Relevance and Efficiency (IM-HERE) project. Subsequently, the government came under further pressure to liberalise its higher education sector as a result of World Trade Organization (WTO) negotiations on trade in services as part of the Doha Round. The result was a series of major initiatives aimed at promoting key elements of the neo-liberal agenda including, as discussed below, ones related to the autonomy of public HEIs and the entry of foreign HEIs.

However, technocratic elements within government and their donor allies continued to encounter strong resistance to their agenda for two main reasons. First, although the collapse of the New Order weakened the predatory political, military, bureaucratic and corporate elements that dominated the New Order, it did not eliminate them. As Vedi Hadiz (2003, 593) among others has argued, these elements were 'able to reinvent themselves through new alliances and vehicles' such as political parties with the result that they maintained instrumental control over the state apparatus notwithstanding the shift to a more democratic political system. In the education sector, for instance, senior staff at the Ministries of Education and Culture and Religious Affairs continued to be recruited largely from the public universities under these Ministries' control, including in most cases the Minister himself. ${ }^{18}$ At the same time, education-related cabinet positions at the national level continued to be given to members of the major Islamic organizations, Muhammadiyah and Nahdatul Ulama, with the former usually being given MoEC and the latter the Ministry of Religious Affairs (MoRA). ${ }^{19}$ The result has been continued capacity on the part of predatory elements to influence higher education policy and its implementation and, in some cases, undermine reform in the process. This is well illustrated by the Angelina Sondakh corruption case in 2011-2012.

\footnotetext{
${ }^{17}$ On the political economy of this period and in particular the IMF rescue package, see Robison and Rosser (1998).

${ }^{18}$ Interview with an informed source, Jakarta, November 2012.

19 Interview with an informed source, Jakarta, November 2012. Note that this pattern changed with the appointment of Mohammad Nuh as Minister of Education and Culture in 2009. Nuh is a member of Nahdatul Ulama.
} 
Angelina Sondakh was a Democratic Party representative in the DPR and member of its powerful budget committee. In September 2012, she was prosecuted for her role in a corruption scandal related to the construction of an athletes' village for the 2011 South East Asia Games and the purchase of laboratory equipment for 16 local universities. It was alleged that she received bribes from a company owned by the Democratic Party's former treasurer, Mohammad Nazaruddin (who himself was convicted of corruption in relation to the scandal in April 2012) to ensure that the projects were included in the government's budget and that the company won the relevant contracts. In January 2013, she was found guilty of corruption and sentenced to 4.5 years jail. During the course of the scandal, it was revealed that Sondakh had met with a number of MoEC officials and university rectors, in some cases in the company of Nazaruddin. In November 2012, the Corruption Eradication Commission (KPK) revealed that the 16 universities' rectors were all being treated as witnesses (saksi) in the case and that it would keep an eye on how facts unfolded in the court. Besides these individuals, several politicians were also implicated in the case including Youth and Sports Minister and senior Democratic party figure Andi Mallarangeng (who was forced to resign from cabinet in December 2012); I Wayan Koster, a House Budget Committee member from the Indonesian Democratic party of Struggle (PDI-P); Democratic Party chairman Anas Urbaningrum and House Budget Committee Deputy Chairman Mirwan Amir, who is also from the Democratic Party (Parlina 2012; Setuningsih 2012; Jurnal Nasional 2012; Amelia 2012).

Second, the collapse of the New Order also increased the scope for popular elements promoting rights-based and nationalist ideas to influence higher education policy. Democratisation removed key obstacles to organisation by groups such as NGOs and university students, making it easier for them to engage in collective action. It also created an incentive for politicians and their political parties to promote redistributive education policies because of their electoral popularity (Rosser et al 2011). Finally, it entailed the establishment of the Constitutional Court which proved to be both relatively accessible to NGOs and ordinary citizens and sympathetic to rights-related and nationalist causes, reflecting the liberal outlook of its judges and the inclusion of a Bill of Rights in the 1945 Constitution as part of the process of Constitutional reform that occurred between 1999 and 2002 (Mietzner 2010). This created a new entry point into the policy-making process for progressive NGO activists, student activists and nationalist intellectuals, albeit one that could only block or frustrate neoliberal reform rather than actively promote adoption of alternative policies. One outcome of the stronger influence of rights-based and nationalist ideas was a change to the 1945 Constitution in 2002 requiring the government to spend at least 20 percent of its budget on education. Although most of the subsequent budget increase was consumed by pay rises for teachers and programs supporting free basic education (Al-Samarrai and Cerdan-Infantes 2013), it contributed to a growing higher education budget over following years (Moeliodihardjo 2013, 9). While the World Bank supported increased funding for education and higher education in particular, it expressed reservations about the Constitutional mandate, particularly to the extent that the 20 percent is exclusive of teachers' salaries and could undermine decentralisation of responsibility for education to district governments (World Bank 2004, 17). 
The overall result has been broad continuation of the centralist and predatory model of higher education established during the New Order-particularly with regards to the three key focus areas examined above: autonomy, competition, and quality control—except for some notable changes vis-a-vis academic freedom.

\section{Autonomy}

Following the onset of economic crisis in 1997 and subsequent collapse of the New Order regime, the technocrats and their donor supporters renewed their push to promote HEI autonomy. In its 1998 report on Indonesia's education sector, the World Bank (1998: 93) argued that 'a lack of autonomy and responsibility at the university level has led to a lack of accountability and transparency at the institutional level'. Shortly thereafter, the World BankBappenas task force on higher education presented a report arguing that: 'Centralised control especially control over financial management, has inhibited universities from taking the role as the driving force of community development. Therefore, decentralized financial management should be followed by decentralization in other aspects' (Moeliodihardjo et al 2001, 230). To promote the agenda, the World Bank agreed to finance the establishment of a new team within the DGHE to develop alternatives for implementing HEI autonomy (Moeliodihardjo et al 2001, 231). At the same time, progressive NGO activists, student groups, and some academics openly called for the removal of authoritarian controls on academic freedom as well as greater democracy in the way in which public HEIs were run (Human Rights Watch 1998; Kompas 1998a; 1998b). Within this context, the government introduced a range of significant changes to its policies vis-à-vis HEI autonomy, although, as we will see, ones that were, in most cases, ultimately watered down or undermined in implementation.

The most prominent of these were changes to the legal status of HEIs. In 1999, the government issued a new regulation ${ }^{20}$ enabling public HEIs to change their legal status to 'state legal entity' (Badan Hukum Milik Negara, or BHMN). Between 2000 and 2006, it then changed the legal status of seven leading public universities - the University of Indonesia, Gadjah Mada University, Bogor Agricultural Institute, Bandung Institute of Technology, North Sumatra University, Indonesia University of Education, and Airlangga University. This was in turn followed by the inclusion of an article in Law 20/2003 on a National Education System (a replacement for Law 2/1989) that (i) required all public and private educational institutions to be 'education legal entities' (badan hukum pendidikan, BHP); (ii) stated that these entities should operate on a not-for-profit basis and manage their financial affairs autonomously; and (iii) called for the enactment of a separate law on BHP that would spell out the details (Article 53). In so doing, the government effectively extended the reach of the new legal status beyond the leading public HEIs to include all HEIs and schools, both public and private. The World Bank supported this policy change through the IM-HERE project, by making enactment of a new law on BHP a key project performance indicator, and, as such, a condition for project disbursements (World Bank 2011). In March 2007, President

\footnotetext{
${ }^{20}$ Government Regulation 61/1999 on the Determination of the State Higher Education Institutions as Legal Entities.
} 
Yudhoyono submitted a draft version of the BHP law to the DPR, initiating the enactment process. $^{21}$

These moves encountered strong resistance from progressive NGO activists, nationalist intellectuals, university student organizations, and various yayasan. The first three groups had broadly similar concerns - that, in shifting the burden of funding education onto students and families, the state was avoiding its obligation to fund education; that fees at public HEIs would skyrocket, making higher education unaffordable for many people; and that higher fees would in turn worsen inequality (Irawan 2007; Darmaningtyas et al 2009; Tilaar 2012). The yayasan, by contrast, feared a loss of control over their HEIs and other educational institutions - and, with that, the financial and other benefits associated with running them-as well as the possibility of tougher reporting and transparency requirements. $^{22}$ As a first effort to stymie reform, ABPPTSI and a group of yayasan launched a Constitutional Court case against Article 53 on Law 20/2003 in September 2006. But this proved premature: in early 2007, the Court decided that it could not rule on the constitutionality of Article 53 until the BHP law had first been enacted. ${ }^{23}$ Unconstrained by this ruling, the national parliament passed the new law on BHP in December 2008.

At this point, the struggle over HEI autonomy shifted back to the Constitutional Court. In 2009, five separate sets of individuals and organisations lodged requests for the Constitutional Court to review the BHP law, one representing the yayasan, two consisting of progressive NGO activists and their offsiders, one consisting of students from the University of Indonesia and the Jakarta National University (both public HEIs), and the fifth consisting of parents of schoolchildren. The latter mobilized to contest the law because, in their view, the law opened up the prospect of increased commercialisation of school education as well as higher education. In support of these groups, Darmaningtyas, Prof. Dr. Winarno Surakhmad, and Prof. Dr. Soedijarto appeared as experts during Court hearings. In 2010, the Court ruled in favour of the groups, declaring the law both unconstitutional and null and void, albeit on grounds that rejected concerns about the impact of autonomy on citizens' rights to education (Mahkamah Konstitusi 2010, 371-404). Instead the court placed greater emphasis on the law's breaches of the right to legal certainty and the problems uniform legal status would create for continued delivery of educational services and achievement of national educational objectives - that is, the core concerns of the yayasan and their association, ABPPTSI (Rosser forthcoming).

This decision forced government technocrats and their donor supporters back to the drawing board and ultimately to water down their approach. As a stop-gap measure, they made changes to existing regulations to provide a legal basis for the continued operation of the public universities that had changed their status to BHMN. In conjunction with the DPR, they then produced a new law on Higher Education (Law 12/2012) that reaffirmed the principle of autonomy for HEIs but included some significant concessions to the groups that had mobilised against the BHP law. First, rather than require private HEIs to become separate

\footnotetext{
${ }^{21}$ Jadual Acara Pembahasan RUU BHP.

${ }^{22}$ Interview with Anies Baswedan, then Rector of Paramadina University and Head of Indonesia Mengajar, Jakarta, November 2012.

${ }^{23}$ Putusan No. 21/PUU-IV/2006.
} 
legal entities, it instead required that their 'implementing bodies' (badan penyelenggara) should be legal entities, including yayasan as one such possibility in this respect. This appeared to accommodate the concerns of yayasan. Second, it provided for a range of options vis-à-vis the legal status of public HEIs, only one of which (state university legal entities or Perguruan Tinggi Negara badan hukum, PTN-BH) was equivalent to BHP in terms of the level of managerial autonomy allowed (World Bank 2014, 42). A subsequent Constitutional Court decision in late 2013 confirmed the constitutionality of PTN-BH status. But the government has since moved slowly in converting public HEIs to PTN-BH doubtless fearing a public backlash if it does so. By May 2014, only seven HEIs had been granted this statusUniversity of Indonesia, Gadjah Mada University, Bogor Agricultural University, Bandung Institute of Technology, Indonesian Education University, North Sumatra University, and Airlangga University. ${ }^{24}$

Similar outcomes prevailed in relation to two other dimensions of the autonomy agenda: autonomy in the appointment of senior managers and financial management. Under the New Order, rectors of public universities were appointed by the President and the Minister of Education and Culture based on a shortlist of three names nominated by academic senates. Following the fall of the New Order, rector appointment processes were 'democratised' so that they were appointed through an electoral process in which staff and students usually participated. However, the Minister of Education was granted 35 per cent of the vote, allowing him to retain enormous influence over the outcome. ${ }^{25}$ With regards to financial autonomy, the government backtracked on moves to grant public HEIs greater control over their own finances. On the one hand, it retained pre-allocated line-by-line budgeting for HEIs, despite committing to increased use of block grants in its 2003-2010 Higher Education Long Term Strategy (World Bank 2013, 48; 2014, 45). On the other hand, it introduced 'complex, detailed rules about tuition rates and collection' at public HEIs that restrict their ability to set their own fees (World Bank 2014, 46). The latter decision appears to be a response to popular concern about commercialisation of higher education. But, besides this, the changes have been broadly consistent with the logic of predation exposed by the Angelina Sondakh scandal in so far as they reinforce decision-making processes susceptible to corruption.

Perhaps the only dimension of HEI autonomy where significant progress has been made since the fall of the New Order has been academic freedom. MoEC has continued to exercise strong control over the programs that HEIs offer, the duration of these programs, standards for degrees, the establishment of new academic programs, and the closure of old ones (World Bank 2014, 44). But the freer political climate of the post-New Order period has substantially increased the scope for academics to voice critical views through their research, teaching and public engagement: as Freedom House (2014) has noted, academic freedom is now 'generally respected' in Indonesia. HEIs also generally have the authority to set their own curricula and accept or reject individual applicants for student places (World Bank 2014,

\footnotetext{
${ }^{24}$ Interview with DGHE official, May 2014.

${ }^{25}$ See Government Regulation 61/1999 on the Establishment of Higher Education Institutions as Legal Entities and Minister of National Education Regulation 24/2010 on the Appointment and Termination of Rectors/Chairpersons/Directors in Higher Education Institutions Run by the Government.
} 
44). This reflects the different politics underlying the issue of academic freedom compared to other aspects of the neoliberal reform agenda. In contrast to these other aspects, academic freedom has been strongly supported by progressive NGOs, student groups, and left-wing and nationalist intellectuals. At the same time, it has encountered relatively little opposition from dominant predatory forces reflecting their ability to operate successfully in the freer, more democratic context of the post-New Order period, although there have been efforts to silence dissent from academics, among other groups, through the use of criminal defamation law and procedures (see Dibley 2011).

\section{Competition}

The post-crisis period also saw the technocrats and their donor allies renew their push to promote the role of the private sector, particularly foreign HEIs, within Indonesia's higher education system. In its 1998 report on Indonesian education policy, the World Bank (1998: 102) argued that the ban of foreign HEIs had undermined the quality of the country's higher education system by reducing competitive pressures and limiting the scope for international partnerships. The government, it argued, should pursue a private sector-led expansion of higher education in which it encouraged foreign universities to participate 'either to spur competition (if established as separate branches) or to provide technical assistance in management (if established in partnership with existing universities)'. But with technocrats and donors having many other fish to fry in the late 1990s-early 2000s, they did not push hard on the issue over the next few years. The World Bank-Bappenas Task Force on Higher Education made no mention of the issue at all in its 2001 report. When the World Bank (2004) prepared its next major report on Indonesia's education system in 2004, it similarly avoided the issue.

In late 2004, however, the issue came back on the agenda as a result of looming international trade negotiations through the World Trade Organisation (WTO). At the end of the Uruguay Round, WTO member countries had agreed to subsequent rounds of negotiations to promote liberalization of trade in services and they were required to nominate ways in which they might contribute to this objective by May 2005. In the lead-up to these negotiations, Indonesia's Minister for Trade, Mari Pangestu, held 'intensive talks' with key stakeholders in Indonesia's education sector to help the government prepare its offer. Rectors at both state and private universities lobbied hard against the removal of restrictions on the entry of foreign universities, suggesting that such liberalization was simply a way for Western universities to generate new business opportunities and would harm domestic HEIs (see Jakarta Post 2004, 2005). But with WTO processes dictating some concessions, Pangestu and her team were unable to concede entirely to their demands. In the end, they presented a compromise to the WTO: the government would open up the higher education sector but with a particular focus on post-secondary technical and vocational education, an area in which few domestic HEIs operated effectively because of the high setup costs. At the same time, they proposed a range of restrictive general conditions including that foreign HEIs 
must operate in conjunction with a local partner, may only operate in particular cities, ${ }^{26}$ and must operate through joint venture limited liability companies (PT) in which they own no more than 49 percent of the equity (World Trade Organisation 2005).

In 2007, President Yudhoyono moved to implement the government's new WTO commitments by including higher education in the government's list of sectors conditionally open to foreign direct investment. ${ }^{27}$ This effort quickly ran aground, however, when it was realised that joint venture PT status conflicted with requirements in Law 20/2003 on a National Education System for educational institutions to operate on a non-for-profit basis (Nandika 2008). The government and the DPR decided to include a provision in the initial draft BHP law related to the role of foreign HEIs in Indonesia but, for unclear reasons, this did not make it through to the final draft. ${ }^{28}$ Eventually, they agreed to insert an article on the role of foreign HEIs in the 2012 Higher Education Law stating that foreign HEIs were permitted to carry out higher education in Indonesia so long as they (i) operated on a not-for profit basis, (ii) cooperated with an Indonesian HEI, (iii) served the national interest, (iv) prioritized the employment of Indonesian citizens, and (v) operated in regions and disciplinary areas approved by the central government. The second and fifth of these conditions were clearly drawn from the earlier WTO commitments while the first reflected the concern to ensure alignment with Law 20/2003 on a National Education System. This article further required that the Minister of Education issue a regulation implementing these provisions.

By the time of writing (April 2015), however, this regulation had not materialised. Following the passage of the Higher Education Law, student groups unsuccessfully challenged the law through the Constitutional Court, as noted above. While driven in large part by concerns about the legal status of HEIs, they were also motivated by a desire to prevent an opening up of the sector to foreign HEIs on the grounds that this would further increase the commercialization, privatization and cost of higher education. ${ }^{29}$ The yayasan that own private universities also indicated that they would challenge the Law through the Constitutional Court because of concern about the competitive pressures that foreign entry would generate - although in the end this did not materialise. ${ }^{30}$ There appear to have been similar anxieties among the leading public HEIs. ${ }^{31}$ Combined together, these factors appear to have persuaded MoEC that the best strategy for the time being is simply to stall by deferring implementation, although it is unclear how long it will be able to continue doing so. The implementation of the ASEAN Economic Community in December 2015 could strengthen MoEC's hand since the agreement calls for trade in services (including higher education) to be liberalised. But this remains to be seen.

\footnotetext{
${ }^{26}$ In the initial offer, these were specified as Jakarta, Bogor, Bandung, Yogyakarta and Medan. Subsequently, the government revised the offer to include Surabaya in place of Bogor, apparently at MoEC's insistence (World Trade Organisation 2008; Nandika 2008).

${ }^{27}$ See Presidential Regulation No. 77/2007 on a List of Sectors that are Closed and Conditionally Open for Investment.

${ }^{28}$ Interview with Satrio Soemantri Brojonegoro, Jakarta, November 2012.

${ }^{29}$ Interview with Yura Pratama and other activists linked to Komnas Pendidikan and LBH Jakarta, Jakarta, November 2012. See also Badan Eksekutif Mahasiswa Universitas Andalas (2012).

${ }^{30}$ Interview with Anies Baswedan, Jakarta, November 2012.

${ }^{31}$ See RMOL (2013).
} 


\section{Accreditation/Quality Control}

During the post-New Order period, government technocrats and their donor supporters have continued to emphasise the need for Indonesia to have an effective accreditation system that provides useful information to prospective higher education students about the quality of educational programs. To this end, they have argued for BAN-PT to have a solid legislative framework, an adequate budget, and rigorous and professional assessment processes (Moeliodihardjo et al 2001, 202-204; Moeliodihardjo 2013, 6-7; World Bank 2014, 36-38). They have been successful with regards to the first of the matters, securing inclusion in the 2012 Higher Education Law of a provision making accreditation compulsory. This is a stronger legislative base for its activities than the lower-level regulations that had previously done so (World Bank 2014, 37). But they have been less successful with regards to the second and third matters.

According to the World Bank (2014, 37), BAN-PT's budget has been sufficient for it to accredit only around 2200 out of more than 16,000 study programs per year. By the end of 2012 , it had consequently only accredited around 60 per cent of all study programs in the country. At the same time, its resources have been so tight that its assessments have typically been cursory rather than thorough and rigorous. Perhaps most importantly for our purposes, they also appear to have been, at least in some cases, subject to manipulation, fraudulent behaviour, and corruption as was the case during the New Order period. For instance, according to Welch $(2007,675)$, it has not been uncommon for engineering faculties at Indonesian HEIs to temporarily borrow equipment from local businesses during BAN-PT assessor visits to enable them to meet accreditation requirements in relation to teaching infrastructure, only to return the equipment once the assessment is done. It is also widely believed that, at least in some cases, accreditation ratings have been bought, although BANPT itself has denied that this is the case, pointing to a favourable evaluation of the organisation by the country's Corruption Eradication Commission (see Suara Merdeka 2010a)..$^{32}$

This situation generated a severe backlash from private HEIs and their representative organisations. Many private HEIs voiced concerns that BAN-PT's tardiness in carrying out assessments jeopardised their survival, given that private HEIs account for around threequarters of the non-accredited programs, accreditation is necessary for recognition of HEIs' qualifications, and MoEC has the authority to close non-accredited institutions and programs. They also questioned the fairness of BAN-PT's assessments, drawing attention in particular to the fact that ratings of public HEIs are on average higher than private HEIs. In 2010, APTISI went so far as to declare that BAN-PT is 'no longer able to handle the accreditation of study programs in Indonesia objectively, transparently, openly, and comprehensively' and call for the establishment of a 'rival' Independent Accreditation Authority (LAM) (Suara Merdeka 2010b). The 2012 Higher Education Law subsequently specified that BAN-PT would in future focus on institutional accreditation while public and private LAMs would be responsible for program accreditation. APTISI responded by promptly establishing its own

\footnotetext{
${ }^{32}$ Interviews with informed parties, Jakarta, May 2014.
} 
LAM and calling on the government to provide funding to support it and other private LAMs (APTISI 2013).

The implications of these changes for the accreditation process are unclear. At first blush, however, they would appear to undermine the integrity of the accreditation process, at least for programs at private HEIs, by placing it under the control of bodies that lack independence from these institutions.

\section{Conclusion}

This paper has examined the extent and pattern of neoliberal higher education reform in Indonesia since the mid-1990s using a political settlements framework. It has argued that reform efforts have been stymied by strong opposition from predatory and popular forces except in relation to academic freedom, an area where popular forces have supported reform and predatory ones offered little resistance. The overall result has been broad continuation of the centralist and predatory model of higher education established during the New Order. Managerial autonomy for public HEIs has remained limited, being granted only to a small number of the country's top universities and then with only limited financial autonomy. Foreign HEIs have effectively been prevented from setting up shop in Indonesia, restricting the level of competition, particularly for the top public and private HEIs. And quality control has remained weak because of an underfunded and non-transparent accreditation system. Underlying this outcome has been the continued political dominance of predatory elements nurtured under the New Order and their corporate clients and the capacity of popular forces to influence policy in the post-New Order period through lobbying and strategic use of the court system. In conceptual terms, the paper suggests a need for scholarship on the politics of higher education reform in developing countries - which has so far focused on the global dynamics driving neoliberal reform - to give greater attention to the role of configurations of power and interest — and the political settlements of which they are part—in mediating global pressures for reform.

In policy terms, the implication of the analysis is that ambitious programs of neoliberal higher education reform are unlikely to succeed in developing countries in the absence of strong of domestic political support, in particular, from the dominant political and social elements and other groups that have access to the policy-making process. This in turn implies that proponents of reform should either (1) pursue a more selective and piecemeal approach centred on promoting reform in areas where domestic political support exists; or (2) devise new global models of reform that are more consistent with political realities in developing countries. Currently, international development organisations are investing significant resources in analytical and policy-related work aimed at helping them to 'think and act politically' (AusAID 2013). The analysis in this paper implies that a less ideological and dogmatic approach, an openness to second-best solutions, and a willingness to countenance alternative models may be a crucial part of this approach at least in relation to higher education.

In broadly rejecting the neoliberal model of higher education, Indonesia has taken a rather different path to other East Asian countries such as China, Singapore, Malaysia and 
Hong Kong. Driven by what Mok (2008) has termed 'market facilitating' or 'market accelerating' states, these countries have combined key elements of the neo-liberal agendaparticularly, opening up of the higher education sector to foreign entrants and limited improvements in HEI autonomy - with pre-existing statist models of higher education in an effort to enhance national economic competitiveness. Notwithstanding the best efforts of technocratic officials and their donor allies, the Indonesian state, by contrast, has proven, to be market retarding due to the nature of the local political settlement surrounding higher education policy and its implementation. In this context, the future challenge for Indonesia is to forge an alternative model of higher education that is simultaneously compatible with this political settlement and productive of better research and teaching outcomes than the present model.

\section{References}

Al-Samarrai, S. and P. Cerdan-Infantes. 2013. "Where Did All the Money Go? Financing Basic Education in Indonesia." In Education in Indonesia, edited by D. Suryadarma and G. Jones, 109-138. Singapore: ISEAS.

Amelia, R. 2012. “Angelina Faces 20 Years in Jail as Bribery Trial Begins.” Jakarta Globe 7 September.

APTISI. 2013. Pernyataan Sikap APTISI Terhadap Isu-Isu Terkini Tentang Pendidikan dan Kebangsaan. 10-12 October, http://untagsmd.ac.id/files/Pernyataan\%20Sikap\%20APTISI\%20 Aceh\%20(RPPP-4\%20APTISI).pdf, accessed 24 October 2014.

Arnove, R. 2009. "World Systems Analysis and Comparative Education in the Age of Globalization." In International Handbook of Comparative Education, edited by R. Cowen and A. Kazamias, 101-119, Dordrecht: Springer.

AusAID. 2013. Thinking and Working Politically: An Evaluation of Policy Dialogue in AusAID. Canberra: Office of Development Effectiveness.

Badan Eksekutif Mahasiswa Universitas Andalas. 2012) "BEN KM UNAND Tolak UU PT." mimeo.

Bassett, R. and A. Maldonado-Maldonado eds. 2009. International Organizations and Higher Education Policy: Thinking Globally, Acting Locally? London: Routledge.

Brojonegoro, S. 2012 "Higher Education Reform." In Otonomi Perguruan Tinggi: Suatu Keniscayaan, edited by S. Irianto, 78-96. Jakarta: Yayasan Buku Obor Indonesia.

Buchori, M. and A. Malik. 2006. "The Evolution of Higher Education in Indonesia." In Asian Universities: Historical Perspectives and Contemporary Challenges, edited by P. Altbach and T. Umakoshi, 249-278. Baltimore: John Hopkins University Press. 
Chua, C. 2004. "Defining Indonesian Chineseness Under the New Order." Journal of Contemporary Asia 34 (4): 465-479.

Cummings, W. 1981. "Pendidikan Tinggi dan Masyarakat Indonesia." Prisma, February: 3449.

Darmaningtyas, E. Subkhan and Fahmi-Panimbang. 2009. Tirani Kapital Dalam Pendidikan: Menolak UU BHP (Badan Hukum Pendidikan). Yogyakarta: Pustaka Yashiba and Damar Press.

Dibley, A. 2011. Criminal Defamation and Democracy in Indonesia. Unpublished Honours dissertation, Australian National University.

Di John, J. and J. Putzel. 2009. Political Settlements: Issues Paper, Birmingham: Governance and Social Development Resource Centre.

Fielden, J. 2008. Global Trends in University Governance. Washington DC: World Bank Education Working Paper Series.

Freedom House. 2014. Indonesia. http://freedomhouse.org/report/freedomworld/2014/indonesia-0, accessed 17 October 2014.

Graf, L. 2009. "Applying the Varieties of Capitalism Approach to Higher Education: Comparing the Internationalisation of German and British Universities," European Journal of Education 44 (4): 569-585.

Hadi, S. 2007. Post Washington Consensus dan Politik Privatisasi di Indonesia. Tangerang: Marjin Kiri.

Hadiz, V. 2003. "Reorganizing Political Power in Indonesia: A Reconsideration of So-called 'Democratic Transitions'.” Pacific Review 16 (4): 591-611.

Hardihardaja, J. 1996. "Private Higher Education in Indonesia: Current Developments and Existing Problems." In Private Higher Education in Asia and the Pacific: Final report, edited by W. Tong-In and Y. Wang. Bangkok: UNESCO PROAP and SEAMEO RIHED.

Hickey, S., K. Sen, and B. Bukenya. 2015. "Exploring the Politics of Inclusive Development: Towards a New Conceptual Approach." In The Politics of Inclusive Development: Interrogating the Evidence, edited by S. Hickey, K. Sen, and B. Bukenya, 3-35. Oxford: Oxford University Press.

Hill D. 1994. The Press in New Order Indonesia, Perth: University of Western Australia Press and Asia Research Centre.

Human Rights Watch. 1998. Academic Freedom in Indonesia: Dismantling Soeharto Era Barriers. New York: Human Rights Watch. 
Idrus, N. 1999. “Towards Quality Higher Education in Indonesia." Quality Assurance in Education 7 (3): 134-141.

Irawan A. 2007. "Ancaman RUU Badan Hukum Pendidikan.” Seputar Indonesia, 18 September, available at: http://www.antikorupsi.org/antikorupsi/?q=node/11316, last accessed 28 January 2013.

Jakarta Post. 1998. "Govt Opens Door to Foreign Universities.” 28 February.

Jakarta Post. 2004. “Govt Committed to Liberalizing Education Sector.” 27 October.

Jakarta Post. 2005. "Indonesia to Offer to Liberalise 7 Service Subsectors at WTO." 24 January.

Jalal, F. and Mustafa B. 2001 eds. Education Reform in the Context of Regional Autonomy: The Case of Indonesia. Jakarta: MoEC and the World Bank.

Johnstone, D., A. Arora, and W. Experton. 1998. The Financing and Management of Higher Education: A Status Report on Worldwide Reforms. Washington DC: World Bank.

Jurnal Nasional. 2012. "KPK Kaji Keterlibatan Rektor", 3 November, available at: http://www.kpk.go.id/modules/news/article.php?storyid=3175, last accessed November 2012.

Khan, M. 2010. "Political Settlements and the Governance of Growth-enhancing Institutions", London: School of Oriental and African Studies, available at: http://core.ac.uk/download/pdf/2792198.pdf, last accessed 2 April 2015.

Khan, M. 2012. "The Political Economy of Inclusive Growth". In Promoting Inclusive Growth: Challenges and Policies edited by Luiz de Mello and Mark Dutz, 15-54. Paris: OECD Publishing.

Kompas. 1998a. "Harapan Untuk Menteri Pendidikan dan Kebudayaan”, 25 May, p.9.

Kompas. 1998b. "Gerakan Pendukung Masyarakat Adil, Terbuka, dan Demokratis", 25 May.

Kristiansen, S. and M. Ramli. 2006. "Buying an Income: The Market for Civil Service Positions in Indonesia." Contemporary Southeast Asia 28(2): 207-233.

Kyodo News. 1997. "Foreign Universities Can Operate in Indonesia”, 29 January.

Leigh B. 1999. "Learning and Knowing Boundaries: Schooling in New Order Indonesia." Sojourn: Journal of Social Issues in Southeast Asia, 14 (1): 34-56.

Lubis, T. 1993. In Search of Human Rights: Legal-Political Dilemmas of Indonesia's New Order, 1966-1990, Jakarta: Gramedia and SPES.

MacIntyre, A. 1990. Business and Politics in Indonesia, Sydney: Allen and Unwin. 
Mahkamah Konstitusi. 2010. Putusan Nomor 11-14-21-126 dan 136/PUU-VII/2009. Jakarta: Mahkamah Konstitusi.

Marginson, S. 2011. "Higher Education in East Asia and Singapore: Rise of the Confucian Model." Higher Education 61: 587-611.

Marginson, S., S. Kaur and E. Sawir. 2011. "Global, Local, and National in the Asia-Pacific". In Higher Education in the Asia-Pacific, edited by S. Marginson, S. Kaur and E. Sawir, 3-34. Dordrecht: Springer.

McLeod, R. 2000. “Soeharto's Indonesia: A Better Class of Corruption.” Agenda 7 (2): 99112.

Mietzner, M. 2010. "Political Conflict Resolution and Democratic Consolidation in Indonesia: The Role of the Constitutional Court." Journal of East Asian Studies, 10 (3): 397424.

Moeliodihardjo, B et al. 2001. "New Paradigm in Higher Education." In Education Reform in the Context of Regional Autonomy: The Case of Indonesia edited by F. Jalal and B. Musthafa, 164-281, Jakarta: MoEC and the World Bank.

Moeliodihardjo, B. 2013. Equity and Access in Higher Education: Revised Final Report. Jakarta: World Bank and Australian Aid.

Mok, K. 2008. "Varieties of Regulatory Regimes in Asia: The Liberalization of the Higher Education Market and Changing Governance in Hong, Kong, Singapore, and Malaysia." Pacific Review 21 (2): 147-170.

Muhr, T. and A. Verger (2009) "Venezuela: Higher Education, Neoliberalism, and Socialism." In The Developing World and State Education: Neoliberal Depredation and Egalitarian Alternatives, edited by D. Hill and E. Roskam, 71-89. London: Routledge.

Naidoo, R. 2011. "Rethinking Development: Higher Education and the New Imperialism.” In Handbook on Globalization and Higher Education, edited by R. King, S. Marginson, and R. Naidoo, 40-58. Cheltenham: Edward Elgar.

Nandika, D. 2008. "Klarifikasi Indonesia - Conditional Initial Offer Sektor Pendidikan Pada Forum WTO." Letter to Ketua Tim Koordinasi Bidang Jasa, Department Keuangan, No. /A.A2.2/LN/2008, 2 May.

Nizam. 2006. “Indonesia.” In Higher Education in South-East Asia. Bangkok: UNESCO.

North, D. 1989. "Institutions and Economic Growth: An Historical Introduction." World Development 17 (9): 1319-1132.

North, D. 1990. Institutions, Institutional Change and Economic Performance. Cambridge: Cambridge University Press. 
North, D. 1994. "Economic Performance Through Time." American Economic Review 84 (3): 359-368.

Nugroho, H. ed. 2002. McDonaldisasi Pendidikan Tinggi. Yogyakarta: Kanisius.

Nugroho, H. 2005. "The Political Economy of Higher Education: The University as an Arena for the Struggle for Power." In Social Science and Power in Indonesia, edited by V. Hadiz and D. Dhakidae, 143-165. Singapore and Jakarta: ISEAS and Equinox.

Parks T. and W. Cole. 2010. Political Settlements: Implications for Development Policy and Practice. Bangkok: Asia Foundation.

Parlina, I. 2012. “Angelina Sondakh: From Beauty Queen to Suspect.” The Jakarta Post, 2 April.

Powell, J. and H. Solga 2010. "Analyzing the Nexus of Higher Education and Vocational Training in Europe: A Comparative Institutional Framework", Studies in Higher Education 35 (6): 705-721.

Prawiro, R. 1998. Indonesia's Struggle for Economic Development: Pragmatism in Action. Oxford: Oxford University Press.

RMOL. 2013. "Kampus Asing Asing Perguruan Tinggi Lokal." http://ekbis.rmol.co/read/2013/02/26/99960/Kampus-Asing-Ancam-Perguruan-Tinggi-Lokal, accessed 2 November 2014.

Robison, R. 1986. Indonesia: The Rise of Capital. Sydney: Allen and Unwin.

Robison, R. and V. Hadiz. 2004. Reorganising Power in Indonesia: The Politics of Oligarchy in an Age of Markets. London: Routledge.

Rosser, A. 1999. 'The Political Economy of Institutional Reform in Indonesia: The Case of Intellectual Property Law." In Law, Capitalism and Power: The Rule of Law and Legal Institutions edited by K. Jayasuriya, 80-99. London: Routledge.

Rosser, A. 2002. The Politics of Economic Liberalisation in Indonesia: State, Market and Power. Richmond: Curzon.

Rosser, A. forthcoming. "Law and the Realisation of Human Rights: Insights from Indonesia's Education Sector." Asian Studies Review.

Rosser, A., D. Edwin, and K. Roesad. 2005. “Indonesia: The Politics of Inclusion”, Journal of Contemporary Asia, 35 (1): 53-77.

Rosser, A., I. Wilson and P. Sulistiyanto. 2011. Leaders, Elites and Coalitions: The Politics of Free Public Services in Decentralised Indonesia. DLP Research Report 16. 
Salmi, J., R. Hopper, and R. Bassett. 2009. "Transforming Higher Education in Developing Countries: The Role of the World Bank." In International Organizations and Higher Education Policy: Thinking Globally, Acting Locally? edited by R. Bassett and A. Maldonado-Maldonado, 99-122. London: Routledge.

Setuningsih, N. 2012. "KPK Calls University Heads in Investigation Linked to Angelina, Nazaruddin." Jakarta Globe 21 June 21.

Soedijarto. 2008. Landasan dan Arah Pendidikan Nasional Kita. Jakarta: Kompas.

Suara Merdeka. 2010a. "BAN PT Untuk Lindungi Mahasiswa." http://suaramerdeka.com/v1/index.php/read/cetak/2010/08/27/121893/BAN-PT-untukLindungi-Mahasiswa, 27 August, accessed 24 October 2014.

Suara Merdeka. 2010b. "APTISI Usul Ban PT Tandingan." http://suaramerdeka.com/v1/index.php/read/cetak/2010/08/25/121615/Aptisi-Usul-BAN-PTTandingan, 25 August, accessed 24 October 2014.

Sujatmoko, B., I. Farida, and L. Wowor. 1998. "Tersandung di Akhir Jabatan." Gatra, 5 September, pp.90-91.

Tilaar, HAR. 2012. Kaleidoskop Pendidikan Nasional: Kumpulan Karangan. Jakarta: Kompas.

Torres, C. and D. Schugurensky. 2002. "The Political Economy of Higher Education in the Era of Neoliberal Globalization: Latin America in Comparative Perspective." Higher Education 43: 429-455.

Varghese, N. 2013. Governance Reforms in Higher Education: A Study of Selected Countries in Africa. Paris: UNESCO.

Varghese, N. and M. Martin. 2013. Governance Reforms and University Autonomy in Asia. Paris: International Institute for Education Planning.

Verger, A., B. Edwards Jnr., and H. Altinyelken. 2014. "Learning from All? The World Bank, Aid Agencies and the Construction of Hegemony in Education for Development." Comparative Education 50 (4): 381-399.

Watson, C. 1986. "Higher Education in Indonesia.” Indonesia Circle 41: 39-44.

Welch, A. 2007 "Blurred Vision? Public and Private Higher Education in Indonesia." Higher Education 54 (5): 665-687.

Wicaksono, T. and D. Friawan. 2011. "Recent Developments in Higher Education in Indonesia: Issues and Challenges." In Financing Higher Education and Economic Development in East Asia, edited by S. Armstrong and B. Chapman, 159-187. EABER. 
Winters, J. 1996. Power in Motion: Capital Mobility and the Indonesian State. Ithaca: Cornell.

World Bank. 1998. Education in Indonesia: From Crisis to Recovery. Washington DC: World Bank.

World Bank. 2000. Higher Education in Developing Countries: Peril and Promise. Washington DC: World Bank.

World Bank. 2004. Education in Indonesia: Managing the Transition to Decentralization. Washington DC: World Bank.

World Bank. 2010. Indonesia: Higher Education Financing. Washington DC: World Bank.

World Bank. 2012. Putting Higher Education to Work: Skills and Research for Growth in East Asia. Washington DC: World Bank.

World Bank. 2013. Implementation Status and Results: Indonesia: Higher Education for Relevance and Efficiency. Report No. ISR7081.

World Bank. 2014. Tertiary Education in Indonesia: Directions for Policy. Jakarta: World Bank.

World Trade Organisation. 2005. Indonesia: Conditional Initial Offer. 22 April, www.ncc.gov.tw/english/files/08091/176_080916_3.doc, accessed November 2012. 


\section{Figures}

Figure 1

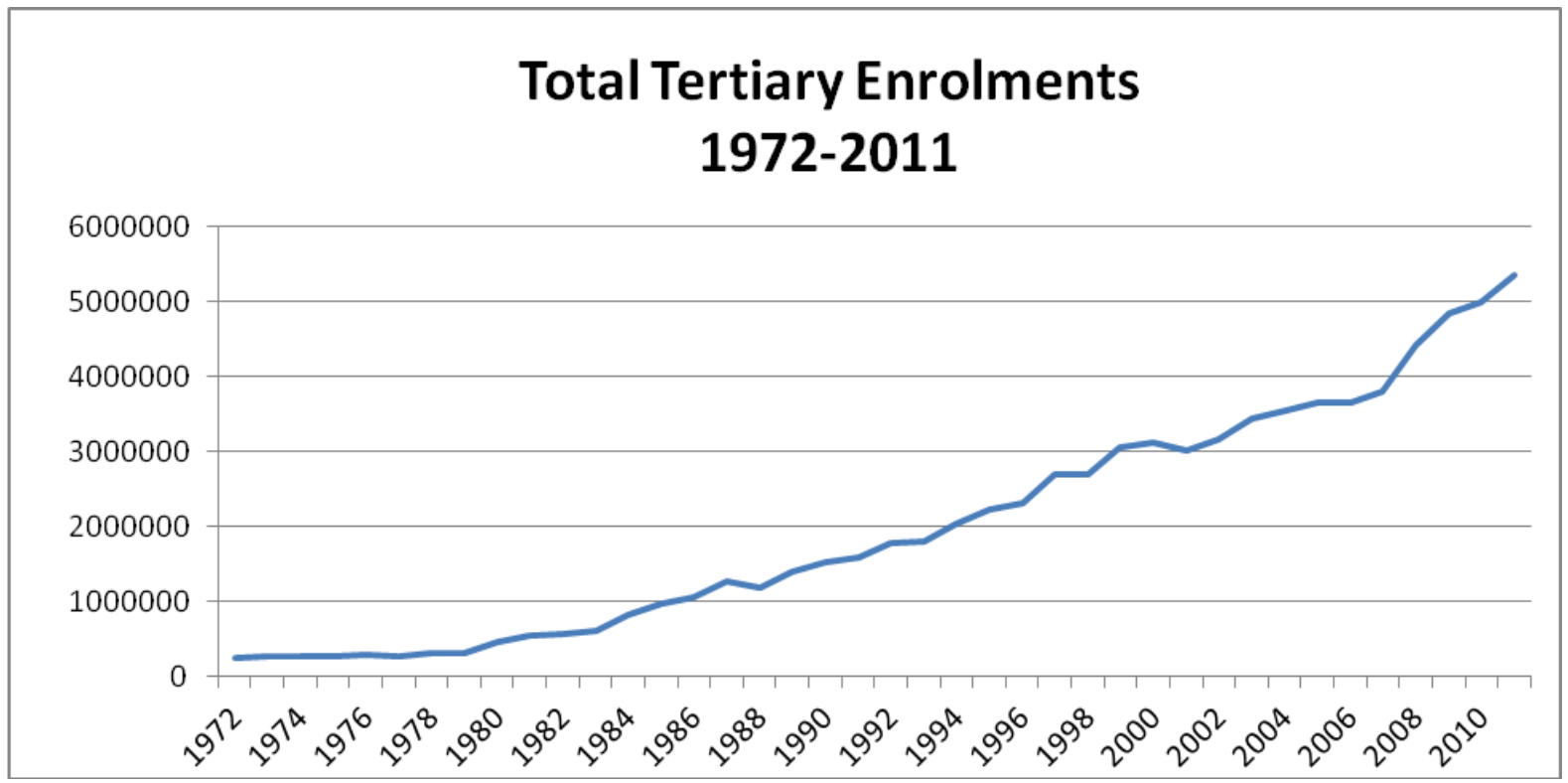

Source: World Bank, World Development Indicators. 
Figure 2: Gross Enrolment Ratio

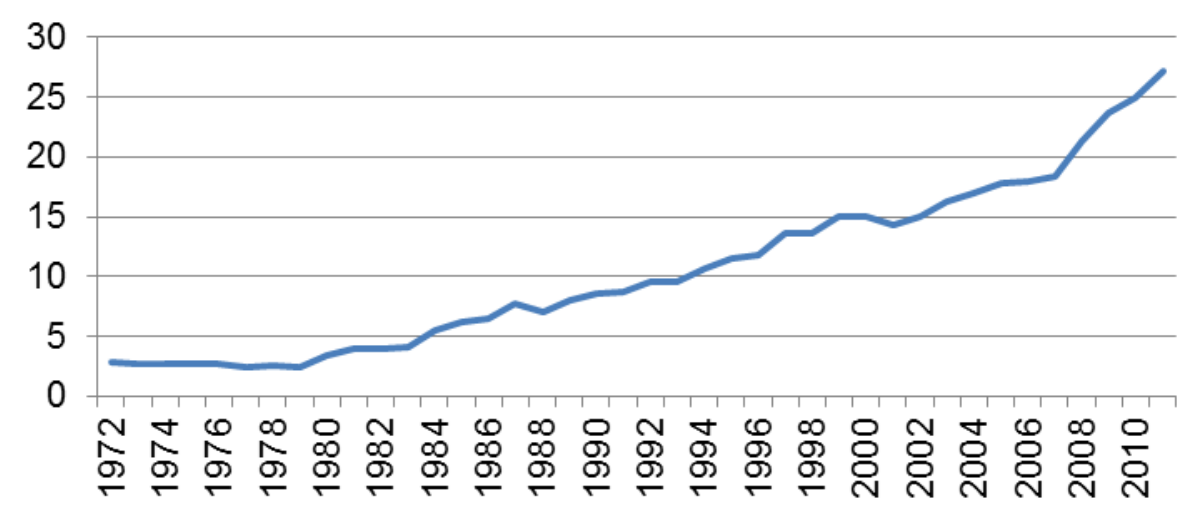

Source: World Bank, World Development Indicators. 


\section{University Library}

\section{- M M I N E R VA A gateway to Melbourne's research publications}

Minerva Access is the Institutional Repository of The University of Melbourne

Author/s:

Rosser, A

Title:

Neo-liberalism and the politics of higher education policy in Indonesia

Date:

2016-01-01

Citation:

Rosser, A. (2016). Neo-liberalism and the politics of higher education policy in Indonesia. COMPARATIVE EDUCATION, 52 (2), pp.109-135. https:// doi.org/10.1080/03050068.2015.1112566.

Persistent Link:

http://hdl.handle.net/11343/268126 